\title{
EFFECTIVE SCHOOL MANAGEMENT AT MAN INSAN CENDEKIA GORONTALO
}

\author{
Najamuddin Petta Solong1, Munirah' ${ }^{2}$, Muh. Arif ${ }^{3}$ \\ 1,3Pascasarjana IAIN Sultan Amai Gorontalo, ${ }^{2}$ FITK IAIN Sultan Amai Gorontalo \\ 1,2,3Jalan Sultan Amai, Kel. Pone, Kec. Limboto Gorontalo \\ Email: uddinpettasolong@gmail.co.id¹, munirah@iaingorontalo.ac.id², \\ muharif@iaingorontalo.ac.id ${ }^{3}$
}

\begin{abstract}
:
This study aims at elaborating the effective school management at MAN Insan Cendekia Gorontalo. This is a descriptive study with qualitative approach. The instruments used in this study were observation sheets, interview guidelines, and questionnaires. The data analysis technique applied descriptive analysis technique using percentage formula. The school management at MAN Insan Cendekia Gorontalo was limited to the following problems: strengths, weaknesses, opportunities, and threats. The research findings showed that the effective madrasah (Islamic school) management at MANInsan Cendekia Gorontalo was achieved. It is concluded that the management of the curriculum, the management of educators and educational staff, the management of funding and the management of facilities and infrastructures, the management of education and the management of public relations are very effective.
\end{abstract}

\begin{abstract}
Abstrak:
Penelitian ini bertujuan untuk menguraikan manajemen sekolah yang efektif di MAN Insan Cendekia Gorontalo. Jenis penelitian ini adalah penelitian deskriptif dengan pendekatan kualitatif. Instrumen yang digunakan dalam penelitian ini adalah lembar observasi, pedoman wawancara, dan kuesioner. Teknik analisis data yang digunakan adalah teknik analisis deskriptif dengan menggunakan rumus persentase. Manajemen sekolah di MAN Insan Cendekia Gorontalo terbatas pada masalah-masalah berikut: kekuatan, kelemahan, peluang, dan ancaman. Hasil penelitian menunjukkan bahwa manajemen madrasah (sekolah Islam) yang efektif di MAN Insan Cendekia Gorontalo telah tercapai. Dapat disimpulkan bahwa manajemen kurikulum, manajemen pendidik dan staf kependidikan, manajemen pendanaan dan manajemen sarana dan prasarana, manajemen pendidikan dan manajemen hubungan masyarakat sangat efektif.
\end{abstract}

\section{Keywords:}

Management, Effective School, MAN Insan Cendekia

How to Cite: Solong, N. P., Munirah, \& Arif, M. (2020). The Analysis of Effective School Management at MAN Insan Cendikia Gorontalo. Lentera Pendidikan : Jurnal Ilmu Tarbiyah dan Keguruan, 23(1), 22-32. https://doi.org/10.24252/lp.2020v23n1i3.

\section{INTRODUCTION}

Facing the era of universalism, all aspects of life must be prepared well in order to anticipate the increasingly fierce competition and to demand for more increasing quality services. It is Included in the field of education, especially in the formal institutions, such as schools. A School is an institution which provides educational services that tries to think 
the effective ways to improve its' costumers' satisfaction as well as fulfill its costumers' needs (the students') by improving the educational quality in the school (Kamayuda, 2016: 16). The educational quality is the whole description and characteristic of educational services both internally and externally that showed its ability in satisfying the expected needs (Sagala, 2010). Furthermore, Sallis (2007) states that quality management is a philosophy about continuous improvement that is able to provide a set of practical tools of every educational institution in fulfilling its costumers' needs, desires and hopes, today and future. Therefore, every school needs to continue improving the educational quality through the effective strategies in order to achieve the students' satisfaction.

The teachers and school principal are the educational personnel who have the most important roles in determining the educational quality. Effective relationships and communications are important in Principal's duty with or without others. The Effective Headmasters can organize themselves and their relationship well (Arhipova, Kokina, \& Rauckiene-Michaelsson, 2018). Fauzi \& Rokhmat (2018) elaborate in theory that the continuity of the Organization's activities can run well if it can place the right person in the right place within the organization. The effective leader is to be able choose the right people in the right place. The school effectiveness refers to the empowerment of all school components as an educational institution based on each main task and function in the program structure in order to make the students learn and achieve the target result (competence)(Nur, Harun, \& Ibrahim, 2016: 94). Supardi (2013: 2) believes that the effective school means that it has the ability to empower every school's important components, both internally and externally, as well as it has a good management system, transparent, and accountable in order to achieve the school's vision-mission-objectives effectively and efficiently. There are also eight management models for school effectiveness, they are; the goal, the input system, the process, the satisfaction, the legitimacy, the ineffectiveness, the organizational learning, and the total quality management model (Cheng, 2013). Salim (2017: 9) states that there are five effectiveness standards that need to be developed in school management, namely: (1) the principle of solid leadership; (2) high expectations of student performance; (3) prioritizing basic skills; (4) appropriate assignments and supervision; and (5) the level of student performance evaluation.Cognitive indicators for monitoring are different. Based on the type of school's effectiveness and school management model, various conceptual possibilities and dilemmas may exist in monitoring school effectiveness due to every school has different effectiveness guidelines or benchmark in educational management.

National Education Association (NEA) provides guidelines for measuring effective schools with three dimensions and indicators. Input dimensions include finance, personality, facilities, equipment, materials, policies and regulations, and student background. Likewise the process dimensions include curriculum and learning, application of policies, diverse educational opportunities, parental involvement, and leadership. Outcome dimensions include academic success, graduation, attitude, class stay and dropouts, school safety, discipline, and the average that continues learning. But this is not the only way to measure effective schools (Kholis, 2015). Schools can be inferred to be 
effective if there are a match and accuracy between the goals and achievement. Effectiveness does not mean describing all aspects that exist; it is a school, which "partially effective" means that the school is effective in achieving one or more specific aspects, but it is not effective in achieving other fields. Nur, Harun, \& Ibrahim (2016: 94) argues that school effectiveness refers to the empowerment of all components of the school as an organization where learning is based on the main tasks and their respective functions in the program structure with the goal that students learn and achieve predetermined results (achieving competence).

Moerdiyanto (2007), believes that success can be achieved in formulating the characteristics of effective schools, they are: (1) the existence of discipline standards that are implemented by school principals, teachers, students, and employees at the school; (2) having regulation of the routine activities in the classroom; (3) having very high school performance standards; (4) students are expected to be able to achieve the planned objectives; (5) students are expected to graduate by mastering academic knowledge; (6) there are awards for students who have achievement; (7) students think that hard work is more important than luck in achieving achievement; (8) students are expected to have generally recognized responsibilities; and (9) the principal of 5 schools has an in-service, supervision, supervision program, and provides time to make plans together with the teachers and allows for feedback for the success of their academic achievement. Various indicators of school effectiveness have potential benefits in the areas of school transparency, self-improvement, and accountability which means that any discussion of school effectiveness measures must begin with a cautionary tale taken from the recent history of federal and state efforts to measure school performance under No Child Left Behind (Association, 2013).

In Indonesia, the school model is an effective policy and practice embodied in the School-Based Quality Improvement Management (SBQIM) program. The reality on the ground refers to Mustiningsih (2015) study that the general problems found in the implementation of School-Based Management (SBM) in elementary schools include the implementation of (1) school-based curriculum management and learning, (2) schoolbased student management; (3) management of educators and school-based education personnel; (4) school-based facilities and infrastructure management; (5) school-based financial management; (6) school-based public relations management; and (7) schoolbased cultural and environmental management. In achieving effective schools, the principal must have a strong role in coordinating, mobilizing, and harmonizing all of the available educational resources. Principal's leadership is one of the factors that can encourage schools in order to aware them about the vision, mission, goals, and objectives of their schools through programs that are implemented in a planned and gradual manner. Sutanta (2013) even believed that the low quality of education is related to the scenario used by the government in developing education that emphasized the input and output approach. Moreover, the identification of characteristics of effective schools is divided into three groups, namely input, process, and output. As in management information systems that emphasize processes, groups the characteristics of effective schools also emphasize 
the educational process. Educational input, as the first characteristic of an effective school, must have clear quality policies, goals, and targets, as in the first paragraph which aims at achieving a clear vision, and mission.

Within the group of effective school characteristics, the latter is output characteristics as expected from the input characteristics. The school's expected output is the school's achievement generated by the learning and management process. In general, the output can be classified into two, they are: output in the form of academic achievement and output in the form of non-academic achievement. Academic achievement output covers grades/ index of achievement, adolescent scientific contest, and various subject fields. Non-academic output includes high curiosity, self-esteem, honesty, good cooperation, high compassion towards others. School management itself is the process of utilizing all school resources carried out through rational and systematic actions (including planning, organizing, mobilizing actions, and controlling) to achieve school goals effectively and efficiently (Nurdin, 2011). Effective school management is planning, implementing, and supervising schools that satisfy school stakeholders. Moreover, the stakeholders are people who care about it, they are: school internal stakeholders, namely students, teachers, and other education personnel, as well as school external stakeholders, namely student guardians, education bureaucrats, community leaders, including figures from non-governmental organizations, entrepreneurs, members of the profession, and alumni (Usman, 2007).

Regarding the description above, there are several reasons that encourage the writer to conduct this research. Firstly, effective school management requires school principals who are able to manage their schools based on strengths, weaknesses, opportunities, and threats faced in developing effective school development strategies. Secondly, empirical studies with this theme are interesting to do in terms of the development of science and management theory, especially the school management that runs rapidly.

\section{RESEARCH METHOD}

This research is a descriptive study which applied qualitative approach that aims to give a description, a systematic, factual and accurate description related tocreate effective school management at MAN Insan Cendekia Gorontalo. The subjects in this study were all vice principals, teachers, administrative staffs, and school committee administrators at MAN Insan Cendekia Gorontalo with a total of 45 people. The instruments used were questionnaires, observation and interview sheets. The data analysis technique is descriptive analysis technique by using percentage formula.

The variables in this study are related to the analysis of effective school management at MAN Insan Gorontalo Scholar which consists of the following variables: strengths, weaknesses, opportunities, and threats possessed in managing effective schools at MAN Insan Cendekia Gorontalo by finding out the assessment scores obtained which based on respondents' answers through research instruments with analysis. The school management at MAN Insan Cendekia Gorontalo is limited to problems; (1) strengths, (2) weaknesses, (3) opportunities, (4) threats. The main data analyzed was qualitative data. 


\section{RESULTS AND DISCUSSION}

\section{Curriculum Management}

The main and fundamental component that needs to be managed properly is the curriculum. Oemar (2010) reveals that the curriculum is an important component and a vital educational tool within the framework of the national education system. Therefore, every educational institution, both formal and informal, must have an appropriate and harmonious curriculum, appropriate to the position, function, role, and objectives of the institution which obviously that curriculum is a standard reference for the implementation of learning programs.

Furthermore, curriculum management is an activity designed to facilitate education managers in carrying out teaching and learning activities that begin from the planning stage and end with program evaluation, so that teaching and learning activities can be well directed. From the search to concepts, the curriculum basically has an understanding dimension, namely curriculum as a subject, a learning experience, and a planning of learning programs. The main activities of curriculum management studies are the areas of curriculum planning, implementation, and improvement. Planning and developing, implementing, administering, evaluating, and improving curriculum run in a mobile system with a continuous cycle, which gradually, in rotation, in the circle of the whole education system process (Oemar, 2010). In line with previous statement that Yoshida (2016) adds that an effective curriculum in every school is aligned with the planning, implementation and assessment processes.

Referring to the position and the function, the curriculum is a design of learning activities for students which includes, objectives, teaching materials, methods, tools, assessments that are interrelated to one another (Widayanti, 2019). The curriculum has developed in educational practice which becomes more oriented towards academic progress, whereas in accordance with national education goals, the spectrum of objectives to be achieved by education is broader than the academic aspect. Nowadays, the purpose of education includes the formation of attitudes, values, and skills are still neglected which becomes an obstacle to the whole human personality.

In term of research findings based on five standards stated in curriculum management, namely content standards, process standards, graduate standards, and educational assessment standards, and management standards, has been carried out by MAN Insan Scholar of Gorontalo very well, namely madrasah which always facilitate the growth of a culture of reading and writing in accordance with madrasah program, madrasah ethic code that has always been a behaviorculturein madrasah, all educators always have systematic assessment documents which means that madrasah periodically always report learning outcomes in the form of daily tests, remedial results, midterm, final exam, and report cards to people old, vision and mission that are always formulated together, socialized, and understood by all interested parties, and manifested in madrasah activities. In addition, madrasah always develop work teams that are supported with organizational structures, division of basic tasks and functions, performance targets and have an achievement evaluation, which always establish partnerships with various parties, 
carry out management supervision through measurable planning, have implementation documents and management quality improvement documents, carry out supervision of learning through measurable planning and have implementation documents and learning quality improvement documents.

\section{Management of Educators and Educational Personnel}

Effective management for school effectiveness is revealed in classroom practices such as frequent homework corrected quickly, ongoing student evaluation and feedback, involving students in class work with close supervision and different treatment as needed helps create a better climate for learning and create school is more effective (Panigrahi, 2014). Erdogan \& Kurt (2015) assert that Effective class management is associated with physical environment setting class, planning management and programming activities, relationship management and communication in the classroom and behavioral students management. The educational personnel management is an effort to organize madrasah personnels in their expertise and social relations, ranging from hired personnel to work for career development. The madrasah principal not only focuses on fostering and developing personnel expertise, but it also focuses on job satisfaction as a key consideration in setting madrasah policies regarding personnel coaching. The management of teacher expertise is directed at their professional abilities more directed at how teachers have social and emotional maturity in interacting among students and personnel (Asmani, 2012). The success of madrasah management depends on the ability and success of the leadership in managing the element of staff consisting of educators and education staff that includes teachers and administrative staffs who are directly involved in learning activities. In this case, the increasing of work productivity and work performance can be conducted by enhancing behavior in the workplace.

Based on the research findings conducted on educators' management and educational staffs at MAN Insan Cendekia Gorontalo, it has been done very well in accordance with the management standards of educators and educational staff. It was shown from the form of management carried out by MAN Insan Cendekia Gorontalo, which is always carrying out mapping needs of educators in accordance with the ratio of needs for each school year, carrying out mapping needs of education staff in accordance with the ratio of needs for each school year, giving an opportunity for every educator and education staff to continue their studies, involving education and training carried out at city/regency or province level, both for teachers and other education personnel, in accordance with the madrasah program, gives every educator the opportunity to participate in MGMP activities. Nevertheless, MAN Insan Cendekia Gorontalo needs to improve competency improvement programs and personal qualifications supported by funding sources in the RKAS, for each year on an ongoing basis, it has and utilizes a system for evaluating the performance of educators and education personnel.

\section{Financial Management}

Education financial management which is also named as education financing is a number of activities related to financial procurement, financial utilization to financial responsibility in order to achieve the objectives of education effectively and efficiently 
(Komariah, 2018). It implies that schools have to know what the cost objectives are, how much is the actual amount of costs required in implementing teaching and learning processes, as well as any programs or activities that need to be funded so that the clarity of the distribution and allocation of funds can be carried out effectively and efficiently and can be accounted for (Kurniady, 2011). Financial standards are standards that govern the components and magnitude of operating costs of education units that are valid for one year (PPRI No. 19 of 2005 concerning National Education Standards, Article 1 paragraph 10). The finance of education consists of investment costs, operating costs, and personal costs. The implementation of these three things above requires the process of planning, organizing, directing, coordinating, supervising, and reporting financial sector activities so that the objectives of the madrasah can be achieved effectively and efficiently.

In accordance with the research findings conducted on the management of finance at MAN Insan Cendekia Gorontalo, it has been done very well related to the standards of financial management. This was shown from the form of management conducted by MAN Insan Cendekia of Gorontalo, which is that madrasah always involve all madrasah stakeholders in every budget discussion/ madrasah program and always report to all stakeholders and display budget performance reports. However, what needs to be improved by MAN Insan Cendekia Gorontalo in financing management is to enhance the effectiveness of budget allocation, increase the average passing score above the national graduation standard, make an effort to have a source of funding, and always facilitate all students to obtain learning opportunities by scholarship support.

\section{Management of Madrasah Facilities and Infrastructure}

Educational facilities are tools and equipment that are directly used and support the educational process, especially the teaching and learning process, such as buildings, classrooms, desks, chairs, and tools and learning media. Ismail, Shahril, \& Mundia (2015) reveal that Effective teaching requires the alignment between the characteristics of teacher and support from school administrators. School administrators must provide a full support initiative and allow teachers to modify their curriculum and teaching strategies. School administrators are also demanded to provide right tools that facilitate teachers in planning their lessons effectively including Internet access, LCD projectors, and so forth. Meanwhile, (Prameswari \& Budiyanto, 2017) argue that school administrators not only support teachers to create new teaching strategies, but they must also allow teachers to acquire learning and teaching resources.

The management of madrasah facilities and infrastructure should be carried out by madrasah, from procurement, maintenance, and repairs to development. It is based on the fact that madrasah are the most aware of the needs of facilities, both adequacy and suitability, and the latest, especially facilities that are very closely related directly to learning. Moreover, the procurement of madrasah facilities has always been dropped from above (central government/ service) that sometimes unfulfilled its needs, especially in the library book procurement and renewal/ renovation of new classrooms. Giving authority to madrasah, can turn out madrasah to become more creative and more independent in managing and adding funds as of the principle of self-funding or self-help returns run 
effectively. The process of managing infrastructure includes five things, namely: determination of needs, procurement, use, management and recording, and accountability.

Referring to the research findings conducted on the management of facilities and infrastructure at MAN Insan Cendekia Gorontalo, it has been carried out in accordance with the management standards of facilities and infrastructure. This was also shown from the form of management carried out by MAN Insan Cendekia of Gorontalo, which always maintains the condition of learning infrastructure facilities well and the condition of the building in good condition, the entire madrasah area becomes clean, beautiful, comfortable, and shady that always carries out a program of procurement of facilities and infrastructure in detail based on the work program that has correlation with APBS and always implements the procurement of facilities and infrastructure programs in the annual work program. Nevertheless, things that need to be improved by MAN Insan Cendekia Gorontalo in the management of facilities and infrastructure is supplying the needs of learning facilities and infrastructure according to the ratio of needs and striving for facilities and infrastructure to function in accordance with the designation, as well as inventory.

\section{Educational Management}

School is the educational organization with principals acting as managers (Yoshida, 2016) which is in line with (Khusni \& Mahmudah, 2020) who argue that School leaders or principals play an important role in determining the direction of the policies they lead. The responsibility of the madrasah principal in managing the educational field is related to the following matters: a) the presence of students in the madrasah and the problems associated with it; b) acceptance, orientation, classification, and appointment of students to class; In this activity, the madrasah principal forms a committee by appointing several teachers to be responsible for the task. After the students are accepted then grouping and orientation are carried out so that they are physically, mentally and emotionally ready to attend education at the madrasah (Mulyasa, 2006); c) evaluation and reporting of learning progress; d) supervision programs for students who have abnormalities, such as teaching, improvement, and exceptional teaching; e) discipline of students; f) student guidance and counseling program; g) health and safety program; h) personal, social and emotional adjustments. Destler (2016) believes that School principal managerial skills play an important role to establish professional learning.

Based on the research findings, it revealed the relationship of students management in terms of planning and acceptance of students, fostering student participation and all students' graduation arrangements which are always conducted by MAN Insan Cendekia Gorontalo by planning the provision of services to students in order to fulfill educational needs, setting the conditions for prospective students to be accepted in the madrasah based on new student admission guidelines, forming a new student admission committee every school year by appointing several teachers to be responsible for the task, determining madrasah capacity or the number of new students to be received by taking into account the number of students living in class or repeating, carrying out the process 
of data collection and service to new students entering to readiness to attend education in madrasah. They must also specify the students into specific classes or study groups, provide orientation or introduction of madrasah to new students, organize and record the attendance of students, record achievements and activities achieved and carried out by students, create rules for regulating student discipline, provide opportunities for students to select extracurricular activities of their interest, determine student graduation based on established graduation standards, record and register students who have graduated and report their learning outcomes in the form of a Letter of Study Completion, and always records and registers students who continue their education.

\section{The Management of Relationships with the Community}

Rosweli (2015) state that the purpose of school relations with the community as follows: firstly, improving the quality of learning and growth of children; secondly, increasing public understanding of the importance of education and improve the quality of people's lives; thirdly, developing an enthusiasm for the spirit of mutual assistance between schools and the community for the progress of both parties.

Based on the findings, the relationship between management with the community at MAN Insan Cendekia Gorontalo was revealed that it has always accommodated information and aspirations from the community regarding the implementation of education in madrasah, and informed to the public about madrasah programs. Moreover, those programs that have been implemented are expected to have a cooperative relationship among this madrasah, other madrasah and the head of the local government.

A more comprehensive review of effective schools is carried out by Davis in Sulaeha (2016) who reveals a set of indicators in the form of 16 factors related to effective schools, namely: (1) parent and environmental support, (2) effective support from the education system, (3) adequate material support, (4) effective leadership, (5) good teaching, (6) flexibility and autonomy, (7) sufficient time in school, (8) high expectations of students, (9) positive attitude from teachers, (10) rules and discipline, (11) organized curriculum, (12) rewards and incentives, (13) adequate learning time, (14) variations in teaching strategies, (15) frequency of homework, and (16) assessments and feedback as often as possible.

\section{CONCLUSION}

Effective madrasah management at MAN Insan Cendekia Gorontalo has been achieved. This was shown from the curriculum management, educators management and education staffs, management of funding and management of facilities and infrastructure, education management, and management of public relations very effectively. However, it should be emphasized that the limitations of this study is it only examined the implementation of the managerial substance of madrasah in the management of financing and the management of facilities and infrastructure, education, and public relations. 


\section{REFERENCES}

Arhipova, O., Kokina, I., \& Rauckienè-Michaelsson, A. (2018). School Principal's Management Competences for Successful School Development. TILTAI, 1. https://doi.org/http://dx.doi.org/10.15181/tbb.v78i1.1757

Asmani, J. M. (2012). Tips Aplikasi Manajemen Sekolah. Diva Press.

Association, N. E. (2013). Multiple Indicators of School Effectiveness. Great Public Schools for Every Student. file://C:/Users/PC/Downloads/Documents/NEAPolicyBriefMultipleMeasures.p df.

Cheng, Y. C. (2013). School Effectiveness \& School-Based Management: A Mechanism For Development. The Falmer Press.

Destler, K. N. (2016). Creating a Performance culture: Incentives, climate, and Organization Change. The American Review of Public Administration, 6(2), 201-225. https://doi.org/https://doi.org/10.1177/0275074014545381.

Erdogan, M., \& Kurt, A. (2015). Science Direct A Review of Research on Classroom Management in Turkey. Procedia -Social and Behavioral Sciences, 186. https://doi.org/10.1016/j.sbspro.2015.04.212.

Fauzi, M., \& Rokhmat, J. (2018). Principal 's Managerial Skill In Improving Teachers ' Performance. IOSR Journal of Research \& Method in Education, 8(3), 77-81. https://doi.org/10.9790/7388-0803047781.

Ismail, S. F. Z. H., Shahrill, M., \& Mundia, L. (2015). Factors Contributing to Effective Mathematics Teaching in Secondary Schools in Brunei Darussalam. Procedia Social and Behavioral Sciences, 186, 474-481. https://doi.org/https://doi.org/10.1016/j.sbspro.2015.04.169.

Kamayuda, D. M. D. (2016). Perencaan Strategi Bersaing Sekolah dalam Meningkatkan Jumlah Peserta Didik Baru di Salah Satu Sekolah Swasta Salatiga. Jurnal Manajemen Pendidikan, 3(1), 15-29. https://doi.org/10.1017/CB09781107415324.004.

Khusni, W., \& Mahmudah, F. N. (2020). the Principal'S Managerial Ability in Developing Effective Schools. International Journal of Educational Management and Innovation, 1(2), 99. https://doi.org/10.12928/ijemi.v1i2.1611.

Komariah, N. (2018). Konsep Manajemen Keuangan Pendidikan. Jurnal Al-Afkar, VI(1). https://doi.org/https://doi.org/10.32520/afkar.v6i1.192.

Kurniady, D. A. (2011). Pengelolaan Pembiayaan Sekolah Dasar. Jurnal Penelitian Pendidikan, 12(1). http://jurnal.upi.edu/1820/view/1368/pengelolaanpembiayaan-sekolah-dasardi-kabupaten-bandung.html.

Moerdiyanto. (2007). Manajemen Sekolah Indonesia yang Efektif melalui Penerapan Total Quality Management. IMEC Proceedings. file:///C:/Users/PC/Downloads/Documents/ARTIKEL MANAJEMEN SEKOLAH EFEKTIF_2.pdf.

Mulyasa, E. (2006). Manajemen Berbasis Sekolah, Konsep, Strategi, dan Implementasi. Remaja Rosdakarya.

Mustiningsih. (2015). Masalah Implementasi Manajemen Berbasis Sekolah di Sekolah Dasar. Manajemen Pendidikan, 24(6), 498-505.

Nur, M., Harun, C. Z., \& Ibrahim, S. (2016). Manajemen Sekolah dalam Meningkatkan Mutu 
Pendidikan Pada SDN Dayah Guci Kabupaten Pidie. Administrasi Pendidikan, 4(1), 93-103. http://www.jurnal.unsyiah.ac.id/JAP/article/view/2611.

Nurdin. (2011). Manajemen Sekolah Efektif dan Unggul. Administrasi Pendidikan, 13(1). https://doi.org/10.17509/jap.v13i1.6387.

Oemar, H. (2010). Manajemen Pengembangan Kurikulum. Remaja Rosdakarya.

Panigrahi, M. R. (2014). School Effectiveness at Primary Level of Education in Relation to Classroom Teaching. International Journal of Instruction, 7(2). https://eric.ed.gov/?id=EJ1085254.

Prameswari, S. J., \& Budiyanto, C. (2017). The Development of the Effective Learning Environment by Creating an Effective Teaching in the Classroom. IJIE (Indonesian $\begin{array}{llll}\text { Journal of } & \text { Informatics }\end{array}$ https://doi.org/10.20961/ijie.v1i1.11960.

Rosweli, E. (2015). Pengelolaan Hubungan Sekolah dan Masyarakat. Makalah. Universitas Siliwangi Tasikmalaya.

Sagala, S. H. (2010). Manajemen Strategik dalam Peningkatan Mutu Pendidikan. PT. Alfabeta.

Salim, N. A. (2017). Peningkatan Efektivitas Pengelolaan Sekolah melalui Penguatan Kemampuan Manajerial Kepala Sekolah. Manajemen Dan Supervisi Pendidikan, 2(1). https://doi.org/https://doi.org/10.17977/um025v2i12017p008.

Sallis, E. (2007). Total Quality Management in Education (Manajemen Mutu Pendidikan). LIRCISoD.

Sulaeha. (2016). Analisis Sekolah Efektif untuk Peningkatan Kualitas Manajemen Terpadu pada Sekolah Dasar. Jurnal Pendidikan, 5(1). file:///C:/Users/PC/Downloads/Documents/garuda908823_3.pdf.

Supardi. (2013). Sekolah Efektif: Konsep Dasar dan Praktinya. Jakarta: Rajawali Pers.

Sutanta, E. (2013). Sistem Informasi Manajemen. Yogyakarta: Graha Ilmu.

Usman, H. (2007). Manajemen Sekolah yang Efektif. Jurnal Pendidikan Inovatif, 3(1). https://jurnaljpi.files.wordpress.com/2009/09/vol-3-no-1-husaini-usman.pdf.

Widayanti, F. E. (2019). Implementasi Kurikulum Ismuba di MI Unggulan Muhammadiyah Lemah Dadi. Al-Tadzkiyyah: Jurnal Pendidikan Islam, 10(1). https://doi.org/https://doi.org/10.24042/atjpi.v10i1.3572.

Yoshida, H. (2016). Effects of Active Learning for Curriculum Management: With Focus on the "Courses of Study" of Japan. International Journal of Knowledge Engineering, 2(2), 77-84. https://doi.org/10.18178/ijke.2016.2.2.057. 